\title{
Molecular Phylogeny of Mugilidae (Teleostei: Perciformes)
}

\author{
D. Aurelle ${ }^{1}$, R.-M. Barthelemy ${ }^{*}, 2$, J.-P. Quignard ${ }^{3}$, M. Trabelsi ${ }^{4}$ and E. Faure ${ }^{2}$ \\ ${ }^{I}$ UMR 6540 DIMAR, Station Marine d'Endoume, Rue de la Batterie des Lions, 13007 Marseille, France \\ ${ }^{2}$ LATP, UMR 6632, Evolution Biologique et Modélisation, case 18, Université de Provence, 3 Place Victor Hugo, 13331 \\ Marseille Cedex 3, France \\ ${ }^{3}$ Laboratoire d'Ichtyologie, Université Montpellier II, 34095 Montpellier, France \\ ${ }^{4}$ Unité de Biologie marine, Faculté des Sciences, Campus Universitaire, 2092 Manar II, Tunis, Tunisie
}

\begin{abstract}
Molecular phylogenetic relationships among five genera and twelve Mugilidae species were investigated using published mitochondrial cytochrome $b$ and $16 S$ rDNA sequences. These analyses suggested the paraphyly of the genus Liza and also that the separation of Liza, Chelon and Oedalechilus might be unnatural. Moreover, all the species of the genus Mugil plus orthologs of Crenimugil crenilabis clustered together; however, molecular analyses suggested possible introgressions in Mugil cephalus and moreover, that fish identified as Mugil curema could correspond to two different species as already shown by karyotypic analyses.
\end{abstract}

Keywords: Mugilidae, grey mullets, mitochondrial DNA, Mugil cephalus, introgression.

\section{INTRODUCTION}

The family Mugilidae, commonly referred to as grey mullets, includes several species which have a worldwide distribution; they inhabit marine, estuarine, and freshwater environments at all latitudes except the Polar Regions [1]; a few spend all their lives in freshwater [2]. They are euryhaline species and can often penetrate lagoons and estuaries, migrating back to the sea to spawn. This family is generally included in the order Perciformes; however, recent authors have considered that this family would constitute a separate order: Perciformes (e.g. [3, 4]).

Within the family, several taxonomic revisions have also been made, raised by the conservative morphology and the paucity of useful taxonomic characters. In a most comprehensive and recent systematic review [1], 14 genera are been identified for a total of 64 valid species. Most of these are included in the genera Mugil and Liza, which have 12 and 23 species respectively. The author of this review recognized 17 nominal taxa in the uncertain condition of species inquirenda [1]. Moreover, the morphological classification stayed conflicted $[2,5]$ and did not provide conclusive answers to phylogenetic questions [6, 7]. Previously, identities of Mugil species have been studied by morphological methods $[1,6]$, protein electrophoresis [8-11], mtDNA analyses $([12,13]$ and references therein). Moreover, 17 nominal species of mugilids that have been karyotyped shown differences within both the Mugil and Liza genera $([14,15]$ and references therein). However, most of these studies provided conflicting results and left numerous phylogenetic questions unsolved including, the relationships within the genera Mugil and Liza.

*Address correspondence to this author at the LATP, UMR 6632, Evolution Biologique et Modélisation, case 18, Université de Provence, 3 Place Victor Hugo, 13331 Marseille cedex 3, France; Tel: (33) 4911063 30;

Fax: (33) 4911062 65; E-mail: roxane.barthelemy@univ-provence.fr
We have focused this study on Mugilid species for which both cytochrome $b$ (cytb) and $16 S$ rDNA mtDNA sequences have been already published. Their geographic distributions are briefly presented here. Oedalechilus labeo is limited to the Mediterranean Sea and the Moroccan Atlantic coast, whereas, Liza and Chelon inhabit also the Eastern Atlantic coasts as well as the Indo-Pacific area [2,16]. Mugil cephalus has a worldwide distribution, occurring in several continental waters [17]. On other Mugil species: M. platanus, $M$. liza and $M$. incilis live on the Western Atlantic Coasts; whereas, $M$. hospes and $M$. curema are distributed on both sides of the American continent [1]. The last species also occurs on the Eastern Atlantic Coasts, from Gambia to Congo $[1,18]$.

In this study molecular phylogenies of mugilids have been established. Moreover, this gave us the opportunity to contribute to the understanding of the rare occurrence of hybridization and/or introgression in marine environments.

\section{MATERIALS AND METHODOLOGY}

Mugilids cytb and $16 S$ rDNA mtDNA sequences have been extracted from GenBank; when identical sequences have been found, only one sequence has been used in the dataset. The characteristics of these sequences are in Table $\mathbf{1}$. The alignments have been made with the BioEdit software [19]. But rare shorter haplotypes, for cytb and $16 S \mathrm{rDNA}$, the alignment lengths were respectively $376 \mathrm{bp}$ and $483 \mathrm{bp}$ (including insertions/deletions).

The methods used for tree reconstructions were:

- Neighbor-Joining algorithm (NJ) applied to the Kimura 2 parameters implemented in the Phylowin software [20].

- $\quad$ Maximum parsimony (MP) with Phylowin.

- Maximum likelihood (ML) using the Guindon and Gascuel's algorithm [21] implemented in the Phyml 
Table 1. Data Concerning the Various Sequences Used for Phylogenetic Analyses (*, Shorter Sequence; N.D., Not Determined)

\begin{tabular}{|c|c|c|c|}
\hline Species & Gene & $\begin{array}{l}\text { Corresponding Name(s) in the Phylogenetic Trees, Number of } \\
\text { Identical Sequences and Accession Number(s) }\end{array}$ & Site of collection \\
\hline $\begin{array}{l}\text { Chelon labrosus Cuvier } 1758 \\
\text { thicklip grey mullet }\end{array}$ & $\begin{array}{l}c y t b \\
16 S\end{array}$ & $\begin{array}{l}\text { C. labrosus. } 1 A \text { (2 identical seq. EF427544, EF427545) } \\
\text { C. labrosus.3Ad (Z70772) } \\
\text { C. labrosus.Ad (AY169697) }\end{array}$ & $\begin{array}{l}\text { A: Cantabric Sea, Spain } \\
\text { Ad: Italy, Lagoon of Venice } \\
\text { Ad: Italy, Valle Figheri }\end{array}$ \\
\hline $\begin{array}{l}\text { Crenimugil crenilabis Forsskål } 1775 \\
\text { fringelip mullet }\end{array}$ & $\begin{array}{l}c y t b \\
16 S\end{array}$ & $\begin{array}{l}\text { C. crenilabis (AP002931) } \\
\text { C. crenilabis (AP002931) }\end{array}$ & $\begin{array}{l}\text { N.D. } \\
\text { N.D. }\end{array}$ \\
\hline $\begin{array}{l}\text { Liza aurata Risso } 1810 \\
\text { golden grey mullet }\end{array}$ & $c y t b$ & $\begin{array}{l}\text { L. aurata.15A (EF427572) } \\
\text { identical to EF439541 } \\
\text { L. aurata.1M (9 seq. EU122431) - L. aurata.2M(1 seq. EU1224312) - } \\
\text { L. aurata.6M (1 seq. EU122433) - L. aurata.7M (1 seq. EU122434) } \\
\text { identical to EF439540 } \\
\text { and group with Z70773* } \\
\text { L. aurata.1M (AY169698) - L. aurata.2M (AY169699) }\end{array}$ & $\begin{array}{l}\text { A: Cantabric Sea, Spain } \\
\text { M } \\
\text { M: Tunisia, Kuriat Islands } \\
\text { M } \\
\text { Ad: Italy, Lagoon of Venice } \\
\text { M: Italy, Orbetello }\end{array}$ \\
\hline $\begin{array}{l}\text { Liza ramada Thomson } 1986 \\
\text { thinlip mullet }\end{array}$ & $\begin{array}{c}c y t b \\
16 S\end{array}$ & $\begin{array}{l}\text { L. ramada.Ad }\left(\mathrm{Z} 70779^{*}\right) \\
\text { L. ramada.1M(AY169700) - L. ramada.2M (AY169701) } \\
\text { group with AY141408* (Liza sp.) }\end{array}$ & $\begin{array}{l}\text { Ad: Italy, Lagoon of Venice } \\
\text { M: Italy, Orbetello } \\
\text { N.D. }\end{array}$ \\
\hline $\begin{array}{l}\text { Liza saliens Risso } 1810 \\
\text { leaping mullet }\end{array}$ & $\begin{array}{r}c y t b \\
16 S\end{array}$ & $\begin{array}{l}\text { L. saliens. } 1 M(\mathrm{EU} 122428), \text { L. saliens.2M (EU122428) } \\
\text { group with Z70774* } \\
\text { L. saliens.M (AY169702) }\end{array}$ & $\begin{array}{l}\text { M: Lion Gulf, France } \\
\text { Ad: Italy, Lagoon of Venice } \\
\text { Ad: Italy, Valle Figheri }\end{array}$ \\
\hline $\begin{array}{l}\text { Mugil curema Valenciennes } 1836 \\
\text { white mullet }\end{array}$ & $16 S$ & $\begin{array}{l}\text { haplotype I: M. curema.1A (8 seq. from EF426363 to EF426367, } \\
\text { EF426370, EF426422, EF426423) - M. curema.6A (EF426368) - M. } \\
\text { curema.7A (EF426369) } \\
\text { haplotype II: M. curema.15A (8 seq. from EF426371 to EF426376) - } \\
\text { M. curema.21A (EF426377) - M. curema.22A (EF426378) } \\
\text { group with DQ225776*, } \\
\text { DQ225775*, } \\
\text { Z70775* } \\
\text { M. curema.11A (DQ225774*) } \\
\text { haplotype I: M. curema.1A (32 seq. from EF397033 to EF397064) - M. } \\
\text { curema.33A (EF397065) - M. curema.34A (EF397066) } \\
\text { haplotype II: M. curema.35A (8 seq. from EF397067 to EF397074) - } \\
\text { M. curema.43A (6 seq. from EF397075 to EF397080) - M. curema.49A } \\
\text { (EF397081) } \\
\text { M.curema.50P (DQ532914) } \\
\text { M. curema.51P (DQ307687) } \\
\text { M. curema.52P (AY947852*) }\end{array}$ & $\begin{array}{l}\text { A: Brasil and Venezuela } \\
\text { A: Brasil } \\
\text { A: Mar Chiquita, Argentina } \\
\text { A: Mar Chiquita, Argentina and } \\
\text { Galveston Bay, USA } \\
\text { A: USA, South Carolin } \\
\text { A: Galveston Bay, USA } \\
\text { A: Brasil and Venezuela } \\
\text { A: Brasil } \\
\text { P } \\
\text { P: East Coast of the Gulf of California, } \\
\text { Mexico } \\
\text { P: California }\end{array}$ \\
\hline $\begin{array}{l}\text { Mugil hospes Jordan and Cuvier } 1895 \\
\text { hospe mullet }\end{array}$ & $\begin{array}{r}c y t b \\
16 S\end{array}$ & $\begin{array}{l}\text { M. hospes. 1A (8 seq. from EF426354 to EF426359, EF426361, } \\
\text { EF426362) - M. hospes. } 7 \text { A (EF426360) } \\
\text { M. hospes.1A (25 seq. from EF397005 to EF397029) - M. hospes.26A } \\
\text { (EF397030)- M. hospes.27A (EF397031) - M. hospes.28A (EF397032) }\end{array}$ & 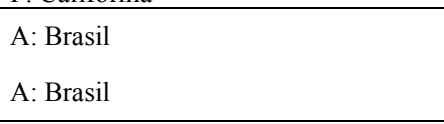 \\
\hline $\begin{array}{l}\text { Mugil incilis Hancock } 1830 \\
\text { parassi mullet }\end{array}$ & $c y t b$ & $\begin{array}{l}\text { M. incilis.1A (11 seq. from EF426379 to EF426383, EF426387, } \\
\text { EF426388, EF426395, EF426397, EF426399, EF426424) - M. in- } \\
\text { cilis.6A (4 seq. from EF426384 to EF426386, EF426390) - M.incilis. } \\
11 A \text { (EF426389) - M. incilis.13A (EF426391) - M. incilis. } 14 A \\
\text { (EF426392) - M. incilis.15A (2 seq. EF426393, EF426400) - M. in- } \\
\text { cilis.16A (EF426394) - M. incilis.18A (EF426396) - M.incilis.20A } \\
\text { (EF426398) } \\
\text { M. incilis.1A (26 seq. from EF397082 to EF397107) - M. incilis.27A } \\
\text { (EF397108) }\end{array}$ & A: Brasil \\
\hline $\begin{array}{l}\text { Mugil liza Valenciennes } 1836 \\
\text { liza }\end{array}$ & $\begin{array}{l}\text { cytb } \\
16 S\end{array}$ & $\begin{array}{l}\text { M. liza.A (9 seq. from EF426401 to EF426407, EF426420, EF426421) } \\
\text { M. liza.A (16 seq. from EF397109 to EF397124) }\end{array}$ & $\begin{array}{l}\text { A: Brasil and Venezuela } \\
\text { A: Brasil and Venezuela }\end{array}$ \\
\hline Mugil platanus Günther 1880 & $\begin{array}{r}c y t b \\
16 S\end{array}$ & $\begin{array}{l}\text { M. platanus. A (8 seq. from EF426408 to EF426415) } \\
3 \text { seq. from EF426416 to EF426418 are identical to M. liza.A } \\
\text { M. platanus. } 13 A \text { (EF397137) - M. platanus.14A (EF397138) - } 12 \text { seq. } \\
\text { from EF397125 to EF397138 are identical to } M \text {. liza.A }\end{array}$ & $\begin{array}{l}\text { A: Brazil } \\
\text { A: Brazil }\end{array}$ \\
\hline $\begin{array}{l}\text { Oedalechilus labeo Cuvier } 1829 \\
\text { boxlip mullet } \\
\text { Elassomatidae Elassoma evergladei } \\
\text { Jordan } 1884 \\
\text { Atherinomorpha Oryzias latipes } \\
\text { Temminck and Schlegel } 1846 \\
\text { Gasterosteiformes Gasterosteus } \\
\text { aculeatus Linnaeus } 1758\end{array}$ & $\begin{array}{l}\text { cytb } \\
16 S \\
\text { cytb } \\
16 S \\
\text { cytb } \\
16 S \\
\text { cytb } \\
16 S\end{array}$ & $\begin{array}{l}\text { O. labeo.Ad (Z70777*) } \\
\text { O. labeo.M (Y169705) } \\
\text { E. evergladei (AP002950) } \\
\text { E. evergladei (AP002950) } \\
\text { O. latipes (AP004421) } \\
\text { O. latipes (AP004421) } \\
\text { G. aculeatus (AP002944) } \\
\text { G. aculeatus (AP002944) }\end{array}$ & $\begin{array}{l}\text { Ad: Italy, Lecce } \\
\text { M: Italy, Livorno } \\
\text { N.D. } \\
\text { N.D. } \\
\text { N.D. } \\
\text { N.D. } \\
\text { N.D. } \\
\text { N.D. }\end{array}$ \\
\hline
\end{tabular}

Abbreviations: A, Atlantic Ocean; Ad, Adriatic Sea; M, Western Mediterranean Sea; I, Indian Ocean; P, Pacific Ocean. 
software. The model of molecular evolution used for reconstruction was chosen with the Modeltest software using the FindModel website at Los Alamos National Laboratory (http://hcv.lanl.gov/content/hcv-db/ findmodel/findmodel.html, accessed 23 July 2008). This allowed us to choose among 28 nucleotide models with the Akaike Information Criteria. The chosen model was a General Time Reversible (GTR) with Gamma distribution of rate variation among sites. The parameter of the Gamma distribution as well as the base frequencies were estimated by the software.

\section{RESULTS}

\section{Molecular Phylogeny Using Partial cytochrome b Gene}

For these analyses, 111 Mugilidae sequences have been extracted from GenBank. Molecular analyses using three reconstruction methods (MP, ML and NJ) give the same general topology. Differences lie in the haplotypes positions inside these groups and in the position of Liza saliens haplotypes. Fig. (1A) presents the ML tree with bootstraps values (BP) which are generally good for inner nodes thereby supporting these main clades. The numbers of variable and informative sites are respectively 198/77, these values being very high for genes used as markers for intra- and interspecific purposes [22].

Mugilidae constitute a monophyletic group highly supported statistically in ML and NJ analyses (BP, 99 and $80 \%$ respectively) but not in MP $(57 \%)$. They are divided in two groups. The first group (named A; BP, NJ:100\%, ML:100\%, MP:69\%) contains all the Mugil sequences plus the ortholog of Crenimugil crenilabis, while the second (B) contains the genera Liza, Chelon and Oedalechilus. Nevertheless this second group is only well supported by NJ (BP: 96\%) but not with MP (28\%) nor ML (<20\%) for which Liza saliens are grouped apart from the other sequences. Within the group $\mathrm{A}$, three monophyletic sub-groups can be shown

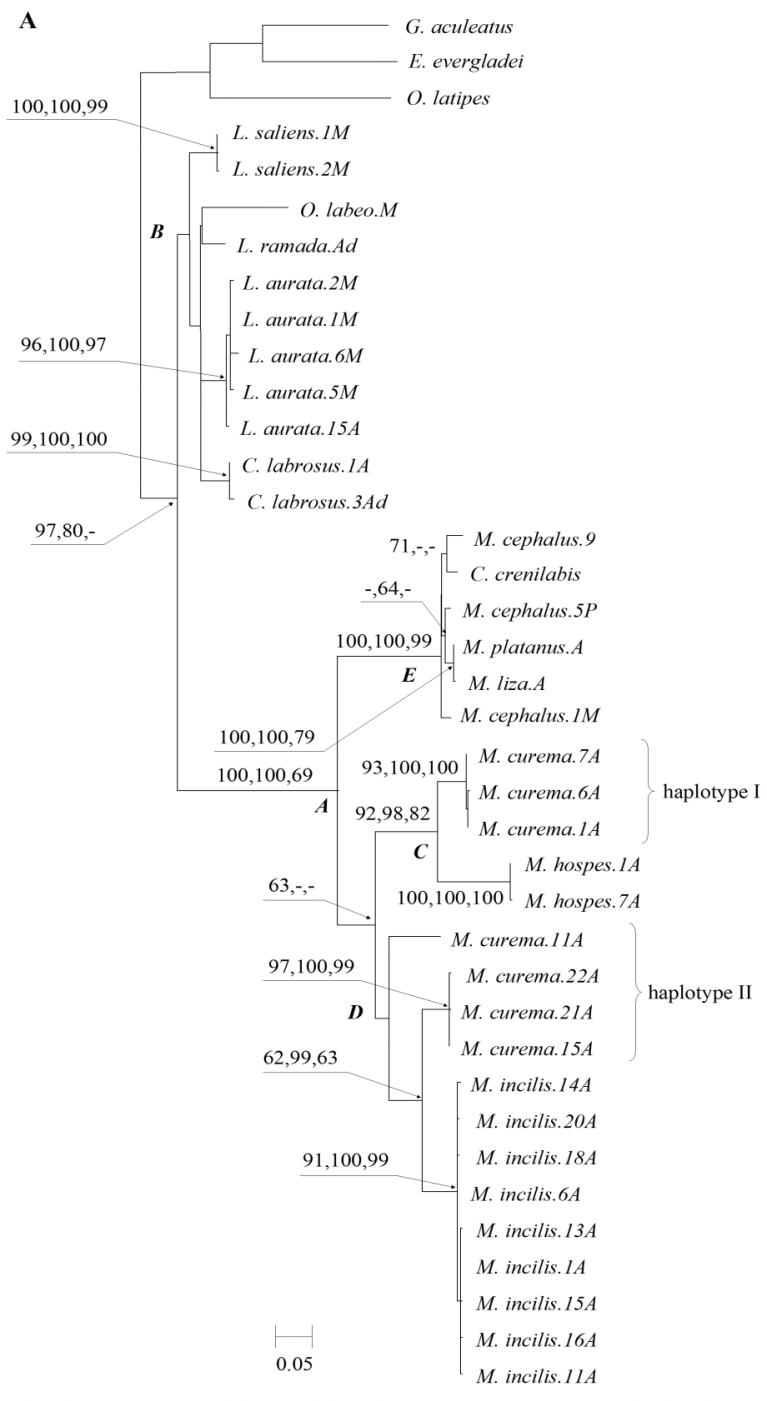

B

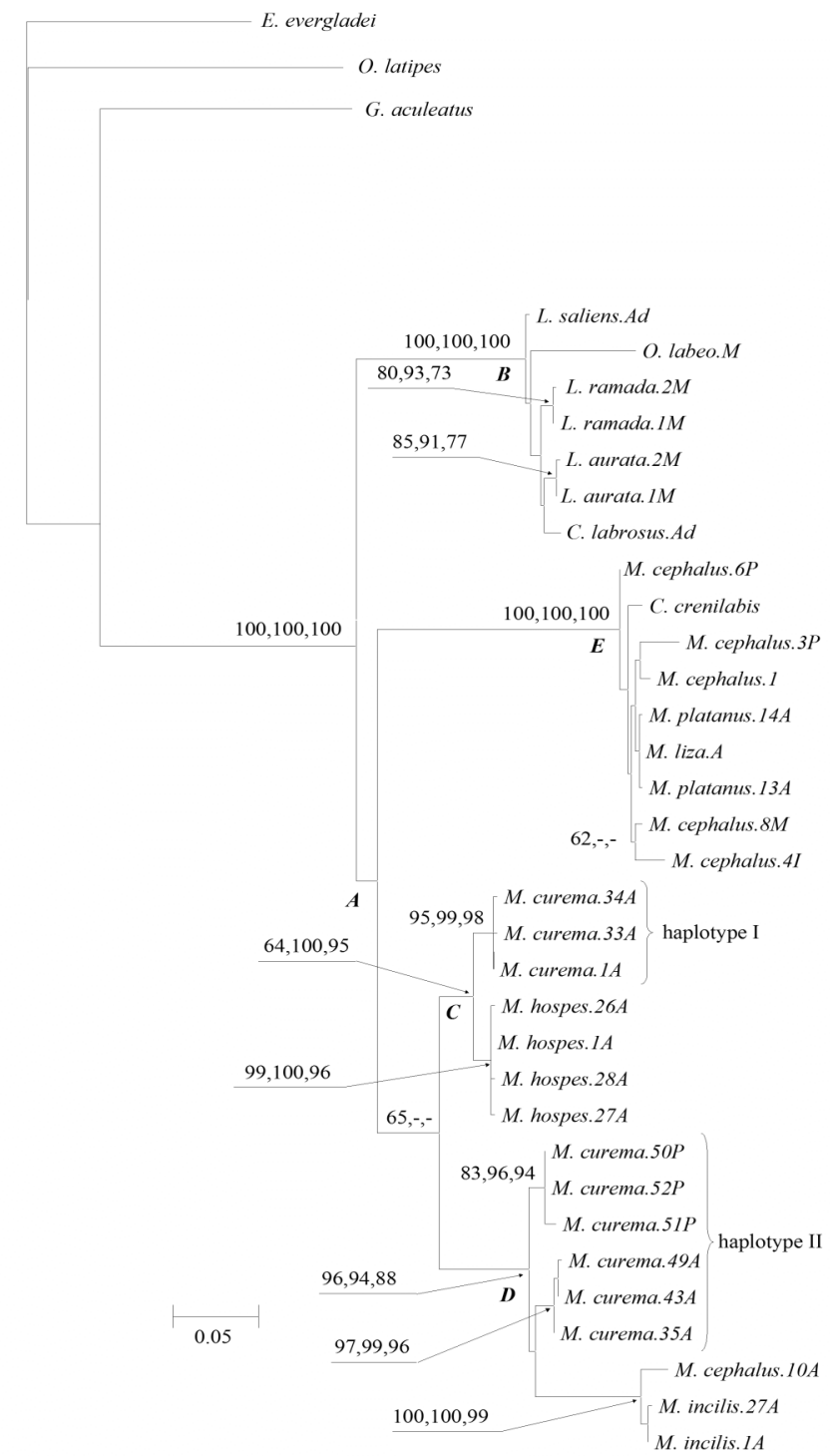

Fig. (1). Phylogenetic trees of Mugilids. A and B, phylogenetic trees using Maximum Likelihood method based on respectively $c y t b$ and $16 S$ $r D N A$ partial sequences. Bootstrap values (BP in \%), carried out with 1000 iterations, are given for each node only if they exceed 60, ML (left BP), NJ (middle BP) and MP (right BP). Sequences from three non mugilids Smegmamorpha (Elassomatidae: Elassoma evergladei; Atherinomorpha: Oryzias latipes; Gasterosteiformes: Gasterosteus aculeatus) have been used as outgroups. 
which are well statistically supported. The M. curema haplotype I sequences constitute a monophyletic group (C) with these of $M$. hospes (BP, ML:92\%, NJ:98\%, MP:82\%). The $M$. curema haplotype II sequences form a sub-group (D) with these of M. incilis (BP, ML:62\%, NJ:99\%, MP:63\%, if not including the sequence $M$. curema 11). This last sequence which came from a fish caught on the US Atlantic Coasts did not group with the sequences of other M. curema caught on this coast. In the sub-group E is constituted by $M$. cephalus, M. platanus, M. liza and C. crenilabis sequences (BP $\geq 99 \%$ ), the M. platanus and M. Liza sequences group together with high bootstrap values (BP, ML:100\%, NJ:100\%, MP:79\%). Surprisingly, on the portion of 507 nucleotides of the cytb gene sequenced, all the M. Liza sequences (from Brazil and Venezuela) are identical between them and identical to three of M. platanus and exhibit only one nucleotide difference with the other M. platanus sequences [13]. Moreover, M. cephalus sequences are divided in three sub-groups, an haplotype groups with the ortholog sequence of C. crenilabis; another haplotype clusters with $M$. liza and M. platanus sequences, whereas the last haplotype is alone [three partial sequences from Balearic archipelago [23] bear this haplotype, data not shown]. However, these groupings are not supported statistically.

The phylogeny of the genera Liza, Chelon and Oedalechilus remains unresolved; indeed, none of the generic and intra-generic (this concerns only Liza) groupings are supported statistically. However, L. aurata and C. labrosus could constitute a clade but this is not statistically supported.

\section{Molecular Phylogeny Using Partial $16 S$ rDNA Gene}

For these analyses, 157 mugilid sequences have been extracted from GenBank. The numbers of variable and informative sites are respectively 161/117. Interestingly, these analyses globally confirm the previous results using the cytb gene, and the trees using three methods (ML, NJ, and MP) gave similar topologies for nodes strongly supported by bootstrap analyses (Fig. 1B). Whatever the outgroup sequences, the Mugilidae are monophyletic (BP 100\% for the three methods). However, if the group B containing the genera Liza, Chelon and Oedalechilus is supported by high bootstrap values (BP:100\%), this is not the case for the group A (Mugil and C. crenilabis sequences) which is recovered with ML (BP:51\%) but appears paraphyletic with NJ and MP, where the group E appears as the sister group of the clade B for NJ, and groups C and D are sister of B for MP; however, this is statistically not supported.

Within the group A, the sub-groups D (BP ML:96\%, NJ:94\%, MP:88\%) and $\mathrm{E}(\mathrm{BP}=100 \%)$ are highly statistically supported. The sub-groups $\mathrm{C}$ and $\mathrm{D}$ are grouped together, but this is not statistically supported (BP $<66 \%$ ). Similarly to cytb analyses, the sub-group $\mathrm{C}$ contains the $M$. curema haplotype I sequences and those of M. hospes; however, this is statistically supported only with two methods (BP, ML:64\%, NJ:100\% and MP:95\%). The sub-group D is constituted by $M$. curema haplotype II sequences, $M$. incilis sequences and one sequence from an Atlantic M. cephalus; this sequence (AC:EF095582) is strictly identical to all the $M$. incilis orthologs, but one which exibits only one ponctual mutation. In the ML analysis, concerning the sub-group E, a part of the M. curema haplotype II sequences has grouped with those of $M$. incilis [and one of M. cephalus], whereas the other M. curema sequences constitute a sister group of this last grouping; however, this is not statistically supported (BP $\leq 58 \%$ ). In NJ and MP analyses, all the M. curema haplotype II sequences could be constitute a clade (BP, NJ: $88 \%$ and MP:55\%). In the sub-group E, all the various branchings are not statistically supported and even the monophyly of the group M. liza/M. platanus is not supported. Moreover, concerning the $16 S r D N A$ partial genes sequenced, all the $M$. liza sequences are identical between them and strictly identical to 12 onto 14 orthologs of M. platanus [13].

The $M$. cephalus sequences do not form an homogeneous group, as some $M$. cephalus haplotypes appear closer to haplotypes from other species. Similarly to cytb analyses, a $M$. cephalus haplotype group with with $M$. platanus and $M$. liza samples $(\mathrm{BP} \leq 54 \%)$, another haplotype has the greatest homology with $C$. crenimugil sequence; whereas the last haplotype contains M. cephalus from Mediterraean Sea (two identical sequences) and one caught in the Indian Ocean. Nevertheless, even if the non-monophyly of $M$. cephalus is suggested by all analyses, they do not agree on the branching order of these sequences.

All $16 S$ rDNA reconstructions indicate the grouping of sequences from Liza, Chelon and Oedalechilus haplotypes (group B). Nevertheless the relationships inside this group are not well defined. In ML analysis, L. saliens sequence could be the sister group of all the other sequences, but this is not supported statistically. Whereas, NJ and MP analyses suggest that Oedalechilus could be the sister group of the two other genera (BP, NJ:95\%, MP:79\%).

Moreover, we have re-analysed two allozyme datasets including: M. cephalus, O. labeo, C. labrosus, L. saliens, $L$. aurata and L. ramada [9, 11] (Fig. 2). However, the UPGMA trees show none branching is statistically supported, and the relationships among these groups are not clear.

\section{DISCUSSION AND CONCLUSION}

\section{Phylogenetical Analyses of the Genera Liza, Chelon and Oedalechilus}

To our knowledge, in all the published molecular studies, but one allozyme analysis [10], the monophyly of the genus Liza has been never supported. However, in all the articles in which species of the genera Liza, Chelon and Oedalechilus have been studied, these three genera constituted a monophyletic group. Studies which used mtDNA sequences [13, 24] (respectively, cytb and $16 S$ rDNA, and cytb and $12 S$ $r D N A)$ and the PCR-RFLP of three mtDNA genes $[12,25]$ have found that $L$. saliens and $C$. labrosus group together. $16 S \mathrm{mtDNA}$ analyses ([9] and present study) suggested a clade L. aurata/C. labrosus; however, this grouping was not statistically supported. Our cytb mtDNA analyses have also suggested this last grouping with weak support and suggested more surprisingly an $O$. Labeo/L. ramada clade. A recent work using allozymes and our $16 \mathrm{~S} r D N A$ analyses, have both shown a C. labrosus/L. Aurata/L. ramada clade [11]. Interestingly, these three species have strictly the same distribution of Nucleus Organizing Regions (NORs) and $5 S$ $r D N A$ sites, which underlined a higher affinity of Chelon to the subgenus Liza (L. Aurata/L. ramada) [26]. Within the genera Liza, Chelon and Oedalechilus, O. labeo appeared to 
A

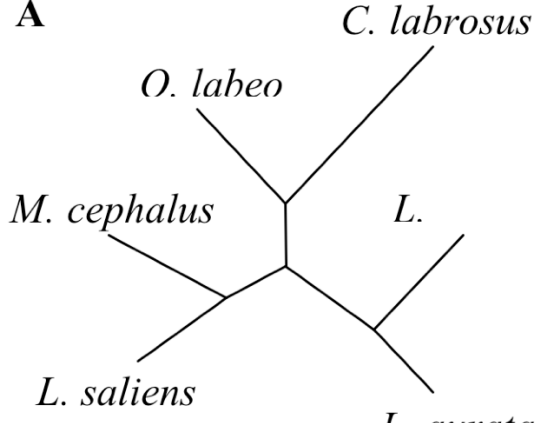

B

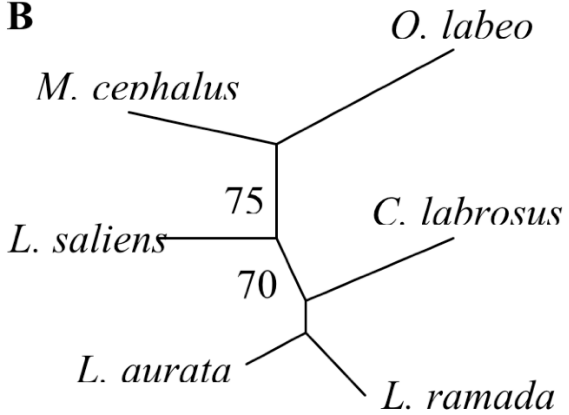

Fig. (2). A and B, reanalysis of the allozyme datasets of respectively Turan et al. (2005) [11] and Rossi et al. (2004) [9], for six species of Mediterranean mullets (M. cephalus, Liza ramada, L. aurata, L. saliens, Chelon labrosus, Oedalechilus labeo) in order to construct an UPGMA dendrogram applied to Cavalli-Sforza's chord measure; robustness of nodes in the dendrogram was analyzed by bootstrapping locus over samples (1000 random permutations of the original data). All calculations were performed using the Phylip software package. In these dendrograms, bootstrap values are given for each node only if they exceed 60.

be the most divergent species in several analyses using various markers: $c y t b$ and $12 S$ rDNA [24], cytb and $16 S$ rDNA [13], both allozymes and $16 S \mathrm{rDNA}$ [9], but not in our $16 \mathrm{~S}$ $r D N A$ analysis using ML method. On the basis of morphological data, it has been suggested a possible paraphyly of Liza with respect to Chelon [6, 27]. On the contrary, studies based on allozyme data $[10,28]$ revealed an appreciable genetic differentiation between Liza and Chelon, verifying, in spite the low number of studied species, the traditional view for the monophyly of genus Liza. In addition, in the latest systematic review, Chelon has considered as a valid genus, "doubtlessly" derived from Liza [1]. All these data contribute to the long systematic debate carried out on these two genera. The difficulty in discriminating Chelon, Oedalechilus and Liza was already revealed by investigations based on chromosome analysis $([14,29]$ and references therein), the three species of Liza, C. labrosus and O. labeo showing one subtelocentric chromosome pair (chromosome pair 24 in both Liza and Chelon and chromosome pair 9 in $O$. labeo) among the remaining acrocentric chromosomes [26]. However, the karyotype of L. saliens differed from those of both the two other Liza species and C. labrosus by the locations of additional $5 S \mathrm{rDNA}$ genes (in a location close to the one shown by major ribosomal genes in $M$. cephalus, i.e. the subtelomeric region of chromosomes 1) and variable $18 S \mathrm{rDNA}$ genes. Moreover, $O$. labeo karyotype differed from the four other species by the locations of both constant and variable $18 S \mathrm{rDNA}$ genes [30]. A karyotypic analysis suggested that L. saliens (named subgenus Protomugil Popov, 1930) can be considered as intermediate between the karyotype of $M$. cephalus which could be the more primitive and those of the other Liza (subgenus Liza) species and of the genus Chelon [26]. According to these authors, Oedalechilus might be a derived branch of Protomugil which could explain the position of this species in the phylogenetic trees, an hypothesis strengthened by the long branches both in $16 \mathrm{~S} r D N A$ and $c y t b$ analyses. Interestingly, in a recent study using both allozymes and $16 \mathrm{~S} r D N A$, L. saliens was the sister group of both the other Liza species and of Chelon [9], but this was not statistically supported, whereas in our $16 S \mathrm{SDNA}$ analyses using ML method, $L$. saliens could be the sister group of the subgenera Liza, Chelon and Oedalechilus.

\section{Phylogenetical Analyses of the Genus Mugil}

Our molecular phylogeny of the genus Mugil revealed several interesting features. Although, Mugilidae constitute a monophyletic group highly supported statistically in ML and NJ analyses, but not in MP, three groups can be found: one group contains some of the sequences of $M$. curema and of $M$. hospes, a second one sequences of $M$. curema and of $M$. incilis; and a last one with M. cephalus, C. crenilabis, M. liza and $M$. platanus sequences.

The grouping of in one hand M. liza and M.platanus, and in another hand $M$. curema and $M$. incilis has been already made using morphological analyses [1] but also by traditional Brazilian populations. Indeed in Brazil, mullets are commonly called tainhas and paratis or curimãs; these two last names are synonyms and their use depend on dialect areas [31]. In Brazil, the Mugil genus consists of seven species and, according to Brazilian inhabitants, two of which are tainhas - M. liza and M. platanus - and five are paratis/curimãs - M. curema, M. incilis, M. trichodon, M. gairmardianus and M. curvidens [18]. Nor, it is well known that folk taxonomy can perceive biotic units similarly to academic scientists [32]; for example, preliterate peoples of New Guinea had vernacular names for 136 out of the 137 native birds recognized as separate species by academically trained Western zoologists [33].

In both cytb and $16 S \mathrm{rDNA}$ analyses, M. liza and $M$. platanus constituted a clade always supported by high bootstrap values ([13] and present study). These two species also share numerous morphological characteristics as ultrastructure of the gills ([34, 35] and references therein). According to a recent study, $M$. liza and $M$. platanus should be treated as a single species or even populations of $M$. cephalus, due to their great similarity in their morphological features and to the fact that they bear the same diploid chromosome number $(\mathrm{n}=48)[13]$.

In our analyses, M. cephalus, C. crenilabis, M. liza and $M$. platanus sequences clustered together. Moreover, in $M$. cephalus, at least three mtDNA haplotypes have been found in $c y t b$ analyses, and one of them has been found for $M$. cephalus sequences (haplotype I) issued from fish caught in the three oceans and the Mediterranean Sea. The $16 S \mathrm{rDNA}$ 
analyses also suggest strong differences between sequences of this species. Within the Mugilids, M. cephalus is the only cosmopolitan species [17]; the variations within the haplotype I could suggest that this species is structured in subpopulations according to a geographic distribution pattern. The clade $M$. liza/M. platanus groups with $M$. cephalus (haplotype II) sequences from fish caught in the Pacific Ocean. Interestingly, the terminal position of NORs on the largest pair of acrocentric chromosomes has been suggested to be the plesiomorphic condition in the genus Mugil, a feature shared by M. cephalus [36], M. platanus [37] and $M$. liza $[9,38]$, but not in the karyotype of other Mugil species analysed to date. Another M. cephalus sequence (haplotype III) group with the ortholog of $C$. crenilabis. The maximum levels of divergence estimated among the $M$. cephalus sequences using cytb and $16 S \mathrm{rDNA}$ (if exclude the sequence which groups with $M$. incilis) datasets are respectively $4.2 \%$ to $3.8 \%$. These levels of nucleotide divergence are in congruence with that proposed by authors of two previous studies among congeneric species $[39,40]$. However, these results show that the various haplotypes of $M$. cephalus sequences do not correspond to geographical haplotypes, but more likely to the incorporation into $M$. cephalus of genome(s) or part of genome(s) (in this case mtDNA genome) of another species (i.e., introgressive hybridization [33]). Indeed, the same haplotype is shared by fish caught in various oceans or seas (suggesting high gene flow capacities of M. cephalus) and each haplotype, but one, is similar to orthologs of other species. In addition, more commonly, genetic exchanges between hybridizing taxa are not reciprocal but directional, in this case, from another species to $M$. cephalus. This, in addition to the fact that, if exclude the sequence which groups with $M$. incilis, none $M$. cephalus sequence is identical to those of other species putatively implied in introgression events could suggest the following evolutionary history life: introgression(s) followed by long periods with great restriction in gene flow and secondary contacts. However, to our knowledge no other studies have shown introgressions in Mugilidae.

Although, our dataset is very partial, it confirms previous morphological analyses showing that $M$. curema, M. hospes and $M$. incilis belong to the same clade (excluding all the other species of our dataset, but one surprising M. cephalus I6S rDNA sequence) [1]. Moreover, morphological analyses also suggest that the two first species are closer relatives than the former [1, 41]. However, for both cytb and $16 S \mathrm{rDNA}$ analyses, some of the $M$. curema sequences grouped with those of $M$. incilis and the others with those of M. hospes. Indeed, two haplotypes of both cytb and $16 S$ rDNA have been found in M. curema species [13]. Their distribution is interesting: in the North and Northeast Brazil the two haplotypes are present in sympatry, in Venezuela only haplotype I has been found, whereas, the haplotype II occurs alone from both the Atlantic (South Brazil, Argentina, USA) and the Pacific (Mexico) Coasts. Moreover, these two different haplotypes have been never obtained from an alone individual. In M. curema, these two haplotypes for both $12 \mathrm{~S} r D N A$ and cytochrome oxydase I sequences have also been shown, as the great molecular proximity of the American and Argentinean individuals, indicating thus that this species does not follow the geographical pattern they expected [23].
Similarly to the two mtDNA haplotypes, two different karyotypes have been found in populations of M. curema. Karyotype I $(2 n=28)$ has been found in fish off Louisiana [42] and South of Brazil [14, 29]; while, karyotype II $(2 \mathrm{n}=$ 24) off Venezuela and North of Brazil [13, 15, 29, 38, 43]. Moreover, the karyotype of South Brazilian M. curema differed from those of Venezuela, besides the diploid number, by the constitutive heterochromatin distribution and NORs location [29]. In addition, morphological comparison revealed differences (both in the number of scales in the lateral line and of the number of pectoral fin rays) in specimens from South of Brazil versus those from Venezuela. Based on geographical considerations and on the coastal habits of the species, it is noteworthy that the farthest away populations (Louisiana and South of Brazil) share a similar chromosome complement, which is different from the one found in the population collected in an area (Venezuela and North of Brazil) which is geographically intermediate. As suggested by these authors, if these two morphs definitely belong to the same species, it would be possible to observe individuals in the wild with an intermediate karyotype between karyotype I and karyotype II (i.e. $2 \mathrm{n}=26$ ); however, in spite of the analysis of 150 samples, individuals with this intermediate karyotype did not find [29]. The cytogenetic and morphologic differences added to the leak of putative hybrid, lead these authors to suggest that both two karyotypes are not merely related to geographic polytipic variations but could correspond to different cryptic species. Moreover, the karyotype I of M. curema is similar to those of $M$. incilis species from Brazil [44, 45], further studies are needed in order to know that of $M$. hospes. With the exception of the $M$. curema $(2 \mathrm{n}=24$ or 28$)$ and $M$. incilis $(2 \mathrm{n}=28)$, the other Mugilid species studied to date have a diploid number of 48 and the primitive teleost karyotype is thought to have consisted of 46-48 chromosomes [42]. Thus, the karyotypes of M. curema and M. incilis suggest a rare occurrence of extensive chromosomal rearrangements among the Mugilids and their derivated karyotypes, are probably originated by centric fusions and pericentric inversions [14].

\section{Supplementary Data on Mugil cephalus}

In spite a relatively low number of sequences, our molecular analyses could suggest that three or more mtDNA haplotypes are present in the $M$. cephalus sequence dataset and that the geographical distribution of these haplotypes does not generate a phylogeographical signal. More data concerning the life history of this species added to analyses of other loci (and particularly nuclear loci) could help to resolve the pattern and the process of the geographical distribution of the haplotypes. The striped mullet, M. cephalus is globally distributed between the latitudes of $51^{\circ} \mathrm{N}$ and $42^{\circ} \mathrm{S}$, although less abundant in tropics [3]. Because of this distribution and the dependency of $M$. cephalus on coastal waters during various phases of its life cycle, questions have been raised regarding levels of genetic divergence and gene flow among transoceanic populations. The notion of cosmopolitan species has been questioned. In general, movement and supposed gene flow for M. cephalus appear to be relatively high along contiguous coastlines [46]. To the exception of one mtDNA study [47], other previous mtDNA [17] and allozyme $[48,49]$ analyses of global populations of $M$. cephalus indicated a pronounced population subdivision for 
the species. Indeed, populations of striped mullets from the Mediterranean Sea and the three oceans showed high levels of genetic divergence and extremely reduced inter-ocean gene flow suggesting that some of the M. cephalus populations are at a stage of incipient speciation [48].

Both mtDNA and allozymic genetic analyses of global populations of $M$. cephalus ([8, 17, 48, 49] and present study) are intriguing for two reasons. Firstly, the genetic heterogeneity found in M. cephalus is in conflict with the pattern of general morphological uniformity highlighted along the distribution range of the species [50]. Genetic differentiation among $M$. cephalus samples is conspicuously higher than that usually found in marine fish with transoceanic distributions which may exhibit little or no genetic divergence among geographically distant populations [22, 51]. This lack of major divergence presumably reflects existing or historical levels of gene flow which is reduced in neretic species. Secondly, based on geographical considerations and on the coastal habits of the species, it is noteworthy that very distant populations share a closer relationship than individuals collected in a geographically adjacent regions. Under the neutral theory, the same factors that promote intraspecific polymorphism (neutral mutation and genetic drift) also result in differentiation between species. As that was already suggested [48], it is therefore plausible to imagine that at a certain moment in the past $M$. cephalus included several isolates, with subdivision favouring the fixation of neutral mutations. The current patterns and degrees of mtDNA variation may then be due, at least in part, to random fixation of alleles in a phase when effective population size was small. Moreover, an accelerated rate of mitochondrial evolution in the genus Mugil has been suggested [47]. However, the considerable genetic differentiation among $M$. cephalus populations, in conjunction with the extremely reduced, or nonexistent, current gene flow, and the presence of several haplotypes led to the hypothesis that the haplotype(s) originated through several introgression events from at least $M$. liza/M. platanus and C. crenilabis. Moreover, if excluded taxonomic misinterpretation is excluded, possible introgression of mtDNA haplotype of $M$. incilis could be also possible, although, the great karyotype differences between the two concerned species [17, 36, 44, 45] probably would render hybridization impossible, and the sympatry of these two species is always discussed.

Our results could suggest introgressions of mtDNA genes in only one direction (from more specialized species to a non specialized species), i.e. from probably more adapted Mugilids species (M. liza/M. platanus, C. crenimugil and putatively $M$. incilis) into the genome of a species with a worldwide distribution (M. cephalus), which may provide physiological advantages to specific ecosystems including unstable environments, and a high tolerance to changes in salinity could be advantageous. Moreover, the fact that the mtDNA gene flow seem to be unidirectional (from one of its sympatric species to $M$. cephalus), could be a strong argument in favour of this hypothesis. The adaptive role of genetic variability has been hypothesized in many teleosts including Mugilids. In a previous study, authors have suggested that natural selection may play a role in shaping allelic frequency changes during the migratory journey of the similar species M. cephalus [52]. Moreover, genetic differ- ences between inland migrating Liza populations and the ones returning to the sea were also demonstrated [53].

\section{CONCLUSION}

The phylogeny of grey mullets has been challenged, at various systematic levels, using many different morphological characters, but the results were always conflicting and did not provide any conclusive answer. Moreover, allozymic, mtDNA and karyotypic studies on several mullet species did not result in a clear phylogenetic figure. As already suggested by previous studies, our analyses showed that the genera Chelon and Oedalechilus clustered together within the genus Liza. However, the separation of Liza, Chelon and Oedalechilus might be unnatural, and the monophyletic origin of the genus Liza is questionable. Indeed, the genus Liza includes more than 20 species, most of which are not yet included in molecular phylogenetic reconstructions; similarly, only one species for both genera Chelon and Oedalechilus has been analysed. A more extensive genetic survey of representatives of these three genera, including also the non-Mediterranean species of Liza, as well as the remaining species of Chelon and Oedalechilus, is needed to contribute to the systematic debate on whether the two genera on the whole should be synonymised or whether they represent distinct clades. Moreover, to state definitively on the monophyly of the genus Liza, needs examination of multiple genetic systems.

More surprisingly, our results do not provide good support for the hypothesis that Mugil is a monophyletic group as it includes a Crenimugil species; however, as only one mitochondrial genome of this genus has been sequenced to date, other sequences data are necessary for further resolution of intrageneric and intergeneric relationships. In the same manner, further studies are needed to look for the existence of two sibling species in the $M$. curema complex, unless that could be the result of ancient vicariance.

In the future, the analyses will carry on several populations of M. cephalus and on the numerous Mugilids sympatric species; this suppose a good morphological identification of these species in order to avoid possible taxonomic misidentifications. In addition, the combination of molecular assays of both nuclear (including microsatellites) and mtDNA will provide the best approach to understand the evolutionary dynamics of these interacting populations. Mating compatibility studies are also needed between $M$. cephalus and the sympatric congeneric species and Crenimugil spp.

Considering the many doubts still existing on the taxonomy and ecology of mullet species, we believe that additional data, including increased geographic and species sampling and nuclear molecular investigations, are necessary. Such studies, along with similar investigations in other species groups, could significantly contribute to our understanding of the evolutionary importance of introgressive hybridization in the oceans.

\section{ACKNOWLEDGEMENTS}

We are indebted to anonymous reviewers who helped in improving of the article. 


\section{REFERENCES}

[1] Thomson JM. The Mugilidae of the World. Mem Queensl Mus 1997; 41: 457-62.

[2] Nelson JS. Fishes of the world. 4th ed. New York: John Wiley and Sons; 2006.

[3] Harrison IJ. Mugilidae: mullets. In: Carpenter KE, Ed. The living marine resources of the western central Atlantic. Vol 2. Bony fishes part 1 (Ascipenseridae to Grammatidae). Rome, FAO Species Identification Guide for Fishery Purposes 2002; 2: 1071-85.

[4] Leis JM, Carson-Ewart BM, Eds. The larvae of Indo-Pacific coastal fishes. An identification guide to marine fish larvae. Fauna Melanesia handbook 2. Leiden: Brill; 2000.

[5] Corti M, Crosetti D. Geographical Variation in the Grey Mullet: A Geometric Morphometric Analysis Using Partial Warp Scores. J Fish Biol 1996; 48: 255-69.

[6] Harrison IJ, Howes GJ. The pharyngobranchial organ of mugilid fishes: its structure, variability, ontogeny, possible function and taxonomic utility. Bull Br Mus (Nat Hist) Zool 1991; 57: 111-32.

[7] Stiassny MLJ. What are grey mullets? Bull Mar Sci 1993; 52: 197219.

[8] Rossi AR, Capula M, Crosetti D, Campton DE, Sola L. Genetic divergence and phylogenetic inferences in five species of Mugilidae (Pisces : Perciformes). Mar Biol 1998; 131: 213-8.

[9] Rossi AR, Ungaro A, De Innocentiis S, Crosetti D, Sola L. Phylogenetic analysis of Mediterranean Mugilids by allozymes and 16S mt-rRNA genes investigation: Are the Mediterranean species of Liza monophyletic? Biochem Genet 2004; 42: 301-15.

[10] Papasotiropoulos V, Klossa-Kilia E, Kilias G, Alahiotis S. Genetic divergence and phylogenetic relationships in grey mullets (Teleostei: Mugilidae) using allozyme data. Biochem Genet 2001; 39: $155-68$.

[11] Turan C, Caliskan M, Kucuktas H. Phylogenetic relationships of nine mullet species (Mugilidae) in the Mediterranean Sea. Hydrobiologia 2005; 532: 45-51.

[12] Papasotiropoulos V, Klossa-Kilia E, Alahiotis SN, Kilias G. Molecular phylogeny of grey mullets (teleostei: mugilidae) in greece: evidence from sequence analysis of mtDNA segments. Biochem Genet 2007; 45: 623-36.

[13] Fraga E, Schneider H, Nirchio M, Santa-Brigida E, RodriguesFilho LF, Sampaio I. Molecular phylogenetic analyses of mullets (Mugilidae, Mugiliformes) based on two mitochondrial genes. J Appl Ichthyol 2007; 23: 598-604.

[14] Cipriano RP. Estudos citogenéticos em teleóteos marinhos pertencentes a Baía de Paranaguá, Paraná, Brasil. Dissertação de Mestrado apresentada ao Programa de Pós-graduação em Genética do Setor de Ciências Biológicas, Departamento de Genética da Universidade Federal do Paraná [dissertation]. 2005 ; [updated 2005; cited 2008 Jul 27] Available from: http://dspace.c3sl.ufpr.br:8080/ dspace/bitstream/1884/2939/1/Mestrado\%20ROGER.pdf

[15] Nirchio M, Oliveira C, Ferreira IA, et al. Análisis comparativo citogenético y aloenzimático de Mugil rubrioculus and M. curema (Teleostei: Mugilidae) de Venezuela. Interciencia 2007; 32: 75762.

[16] Baltz DM. Introduced fishes in marine systems and inland seas. Biol Conserv 1991; 56: 151-77.

[17] http://www.sciencedirect.com/science? ob=ArticleURL\& udi=B6 T8F-44NM8S3-1\&_user $=1492585 \& \_$coverDate $=02 \% 2 \mathrm{~F} 28 \% 2 \mathrm{~F} 20$ $02 \&$ alid $=594070446 \&$ rdoc $=3 \&$ fmt $=$ full \& orig $=$ search \& cdi $=5$ $085 \&$ sort $=\mathrm{d} \&$ st $=0$ \& docanchor $=\&$ ct $=4 \&$ acct $=\mathrm{C} 000037459 \&$ _version $=1 \& \_$urlVersion $=0 \& \_$userid $=1492585 \& \mathrm{md} 5=$ cd $962 \mathrm{f} 2 \mathrm{f} 58 \mathrm{f}$ cc6bca14050cc14bfcc8c - bbib29Crosetti D, Nelson WS, Avise JC. Pronounced genetic structure of mitochondrial DNA among populations of the circumglobally distributed grey mullet (Mugil cephalus). J Fish Biol 1994; 44: 47-58.

[18] Menezes NA. Guia prático para conhecimento e identificação de tainhas e paratis (Pisces, Mugilidae) do litoral brasileiro. Rev Bras Zool 1983; 2: 1-12.

[19] Hall TA. BioEdit: a user-friendly biological sequence alignment editor and analysis program for Windows 95/98/NT. Nucleic Acids Symp Ser 1999; 41: 95-8.

[20] Galtier N, Gouy M, Gautier C. SEAVIEW and PHYLO_WIN two graphical tools for sequence alignment and moleculer phylogeny. CABIOS 1996; 12: 543-8.

[21] Guindon S, Gascuel O. A simple, fast, and accurate algorithm to estimate large phylogenies by maximum likelihood. Syst Biol 2003; 52: 696-704.
[22] Trabelsi M, Gilles A, Fleury C, Maamouri F, Quignard JP, Faure E. Atherina punctata and Atherina lagunae (Pisces, Atherinidae), new species found in the Mediterranean sea. 2. Molecular investigations of three Atherinid species. CR Acad Sci Paris, ser III 2002; 325 $1119-28$

[23] Heras S, Castro MG, Roldan MI. Mugil curema in Argentinean waters: Combined morphological and molecular approach. Aquaculture 2006; 261: 473-8.

[24] Caldara F, Bargelloni L, Ostellari L, Penzo E, Colombo L, Patarnello T. Molecular phylogeny of grey mullets based on mitochondrial DNA sequence analysis: evidence of a differential rate of evolution at the intrafamily level. Mol Phylogenet Evol 1996; 6: 41624.

[25] Papasotiropoulos V, Klossa-Kilia E, Kilias G, Alahiotis S. Genetic divergence and phylogenetic relationships in grey mullets (Teleostei: Mugilidae) based on PCR-RFLP analysis of mtDNA segments. Biochem Genet 2002; 40: 71-86.

[26] Gornung E, Cordisco CA, Rossi AR, Innocentiis DS, Crosetti D, Sola L. Chromosomal evolution in Mugilidae: karyotype characterization of Liza saliens and comparative localization of major and minor ribosomal genes in the six Mediterranean mullets. Mar Biol 2001; 139: 55-60.

[27] Senou H, Randall JE, Okiyama M. Chelon persicus, a new species of mullets (Perciformes: Mugilidae) from the persian Gulf. Bull Kanagawa Prefect Fish Exp Stn 1996; 25: 71-6.

[28] Autem M, Bonhomme F. Eléments de systématique chez les mugilidés de Méditerranée. Biochem Syst Ecol 1980; 8: 305-8.

[29] Nirchio M, Cipriano RR, Cestari MM, Fenocchio AS. Cytogenetical and morphological features reveal significant differences among Venezuelan and Brazilian samples of Mugil curema (Teleostei: Mugilidae). Neotrop Ichthyol 2005; 3: 107-10.

[30] Gornung E, Mannarelli ME, Rossi AR, Sola L. Chromosomal evolution in Mugilidae (Pisces, Mugiliformes): FISH mapping of the (TTAGGG)(n) telomeric repeat in the six Mediterranean mullets. Hereditas 2004; 140: 158-9.

[31] Braga FmdeS. Estudo morfológico comparativo das espécies do gênero Mugil linnaeus, da costa brasileira $\left(3^{\circ}-33^{\circ} \mathrm{S}\right)$. Master's thesis, Instituto Oceanográfico, Universidade de Sào Paulo, São Paulo. $1998 ; 174 \mathrm{p}$

[32] Diamond JD. Zoological classification of a primitive people Science 1996; 151: 1102-4.

[33] Mayr E. Animal Species and Evolution. Cambridge, MA: Harvard University Press; 1963.

[34] Eiras-Stofella DR, Charvet-Almeida P, Fanta E, Vianna AC. Surface ultrastructure of the gills of the mullets Mugil curema, M. liza and M. platanus (Mugilidae, Pisces). J Morphol 2001; 247: 122-33.

[35] Cousseau MB, Castro MG, Figueroa DE, Gosztonyi AE. Does Mugil liza Valenciennes 1836 (Teleostei: Mugiliformes) occur in Argentinean waters? Rev Biol Mar Oceanogr 2005; 40: 133-40.

[36] Rossi AR, Crosetti D, Gornung E, Sola L. Cytogenetic analysis of global populations of Mugil cephalus (striped mullet) by different staining techniques and fluorescent in situ hybridization. Heredity $1996 ; 76: 77-82$.

[37] Jordão L, Oliveira C, Foresti F, Godinho HM. Caracterização citogenética da tainha, Mugil platanus (Pisces, Mugilidae). Bol Inst Pesca Sao Paulo 1992; 19: 63-6.

[38] Nirchio M, Cequea H. Karyology of Mugil liza and M. curema from Venezuela. Bol Investig Mar Costeras 1998; 27: 45-50.

[39] Avise JC, Arnold J, Ball RM, et al. Intraspecific phylogeography: the mitochondrial bridge between population genetics and systematics. Annu Rev Ecol Syst 1987; 18: 489-522.

[40] Moritz C, Dowling TE, Brown WM. Evolution of animal mitochondrial DNA: relevance for population biology and systematics. Annu Rev Ecol Syst 1987; 18: 269-92.

[41] Ebeling AW. The dentition of eastern pacific mullets, with special reference to adaptation and taxonomy. Copeia 1957; 3: 173-85.

[42] LeGrande WH, Fitzsimons JM. Karyology of the Mullets Mugil curema and M. cephalus (Perciformes: Mugilidae) from Louisiana. Copeia 1976; 2: 388-91

[43] Nirchio M, Cervigon F, Porto JIR, Perez JE, Gomez JA, Villalaz J Karyotype supporting Mugil curema Valenciennes, 1836 and Mugil gaimardianus Desmarest, 1831 (Mugilidae: Teleostei) as two valid nominal species. Sci Mar 2003; 67: 113-5.

[44] Pauls E, Baretto NMRC, Affonso PRAM, et al. Estudos cacriotípicos em Mugil incilis (Mugilidae, Perciformes) da Baía de Ilha Grande. In: Beker WD, Ed. Programa do VII Simpósio de Citoge- 
nética Aplicada a Peixes Neotropicais; 1998: Londrina, Universidade Estadual de Londrina; 1998; p. 68.

[45] Pauls E, Coutinho IA, Affonso PRAM, et al. Characterization of fish diversity along the coast of the state of Rio de Janeiro: a cytogenetic approach. In: Guedes W, Afonso A, EDs. Proceedings of the First International Workshop on Marine Genetics, 1998: Rio de Janeiro: Universidade Estadual de Rio de Janeiro; 1998; p. 58.

[46] Thomson JM The movements and migrations of mullet (Mugil cephalus L.). Aust J Mar Freshw Res 1955; 6: 328-347.

[47] Rocha-Olivares A, Garber NM, Stuck KC. High genetic diversity, large inter-oceanic divergence and historical demography of the striped mullet. J Fish Biol 2000; 57: 1134-49.

[48] Rossi AR, Capula M, Crosetti D, Campton DE, Sola L. Allozyme variation in global populations of striped mullet, Mugil cephalus (Pisces : Mugilidae). Mar Biol 1988; 131: 203-12.
[49] Rosenblatt RH, Waples RS. A genetic comparison of allopatric populations of shore fish species from the eastern and central $\mathrm{Pa}-$ cific Ocean: dispersal or vicariance? Copeia 1986; 2: 275-84.

[50] Thomson JM. The taxonomy of grey mullets. In: Oren OH, Ed. Aquaculture of Grey Mullets. Cambridge, Cambridge Univ Press $1981 ; 1-15$.

[51] Gilles A, Miquelis A, Quignard JP, Faure E. Molecular phylogeography of western Mediterranean dusky grouper Epinephelus marginatus. CR Acad Sci Paris, ser III 2000; 323: 195-205.

[52] Huang CS, Weng CF, Lee SC. Distinguishing two types of gray mullet, Mugil cephalus L. (Mugiliformes: Mugilidae), by using glucose-6-phosphate isomerase (GPI) allozymes with special reference to enzyme activities. J Comp Physiol B 2001; 171: 387-94.

[53] Papa R, Marzano FN, Rossi V, Gandolfi G. Genetic diversity and adaptability of two species of Mugilidae (Teleostei : Perciformes) of the Po river delta coastal lagoons. Oceanol Acta 2003; 26: 121 8 .

(C) Aurelle et al.; Licensee Bentham Open.

This is an open access article licensed under the terms of the Creative Commons Attribution Non-Commercial License (http://creativecommons.org/licenses/by$\mathrm{nc} / 3.0 /$ ) which permits unrestricted, non-commercial use, distribution and reproduction in any medium, provided the work is properly cited. 